\title{
Information, cooperation, and the blurring of boundaries - technology transfer in German and American discourses
}

\author{
GEORG KRÜCKEN ${ }^{1}$, FRANK MEIER ${ }^{2} \&$ ANDRE MÜLLER ${ }^{3}$ \\ ${ }^{I}$ Science Organization, Higher Education and Science Management, \\ German University of Administrative Sciences, Speyer \\ Freiherr-vom-Stein-Str. 2, 67346 Speyer, Germany \\ (E-mail: kruecken@dhv-speyer.de) \\ ${ }^{2}$ Faculty of Sociology and the Institute for Science and Technology Studies (IWT) \\ Bielefeld University, Universitätsstrasse 25, 33615 Bielefeld, Germany \\ (E-mail: frank.meier1@uni-bielefeld.de) \\ ${ }^{3}$ Institute for Research Information and Quality Assurance (IFQ), Bonn \\ Godesberger Allee 90, 53175 Bonn \\ (E-mail: mueller@forschungsinfo.de)
}

\begin{abstract}
The aim of this paper is to examine changing discursive conceptualizations of technology transfer mechanisms for speeding up innovation in Germany and the US since World War II with particular emphasis on universities. According to our analysis, the concepts of technology transfer are getting more and more complex, taking off from a linear model of innovation to a more complex model allowing for networking and entrepreneurial activities of the universities themselves. We suggest that the discourses in both countries can be framed employing three ideal-typical models: the information and documentation model, the cooperation model, and the blurring of boundaries model. In addition to these similarities, we also discuss differences that can be traced back to broader political cultures in which technology transfer is embedded. Both similarities and differences allow for a comparative perspective which is not limited to the countries analyzed here.
\end{abstract}

Keywords: comparison of US and Germany, entrepreneurial universities, innovation networks, political cultures of innovation, university-industry cooperation

\section{Introduction}

All over the globe, there are debates about the increasingly close relationship between academia and industry (see, for example, Slaughter and Leslie 1997; Etzkowitz et al. 1998; Etzkowitz 2000; Slaughter and Rhoades 2004). Yet, despite arguments about international convergence around new academic-private partnerships, higher education systems continue to differ in important ways. For example, the United States and German university systems exhibit obvious structural differences in 
size, governing structures and internal organization. Moreover, they are embedded in very different cultural traditions. During the second half of the 19th century, the United States higher education system in large part began to incorporate "service" to its socio-economic and socio-political environments as a third academic mission. Later on, it was explicitly seen as a resource for military-related industrial development and it rapidly expanded following World War II. In contrast, the German system, modeled after the 19th century reformist ideals of Wilhelm von Humboldt, has traditionally been characterized by a strong rejection of industry "interference" in higher education. After World War II, as a reaction against the wartime mobilization of university resources by the Nazis, the von Humboldt ideals had been reaffirmed. In this paper, we explore the question of academia and industry ties within an explicitly comparative context.

Specifically, we examine academic-industry ties within the American and German contexts, asking: is the discourse on the "entrepreneurial university" converging across national contexts? Or, do important national differences persist in contemporary discourses about the entrepreneurial university? Based on the analysis of American and German policy documents, ${ }^{1}$ we develop three ideal-typical models of "technology transfer" across the academic and industry divide, which can be found in both national contexts: (1) the information and documentation (I \& D) model; (2) the cooperation model and (3) the blurring of boundaries $(\mathrm{BoB})$ model. We trace the historical rise of each of these models in the United States and Germany, noting the different phases of their (discursive) adoption in each nation's higher education system. Our findings suggest that discourses about academia and industry ties exhibit both transnational and national features. ${ }^{2}$ Though we find strikingly similar general models in both countries, the pace of their adoption and their specific content differ strongly. As it is our aim to frame university-industry relations within the broader context of science in society, we see how a currently hotly debated issue in the field of higher education has been shaped by more general discourses on knowledge, innovation, and the societal utilization of research. This implies to begin our analysis with efforts to improve the transfer of knowledge and technology from public research institutions. These efforts, which provide the background for what we label "information and documentation model", can be seen as a forerunner for contemporary political discourses on university-industry relations. 


\section{The information and documentation model}

According to the I \& D model, the key problem in linking up science and industry is the accelerating rate at which scientific knowledge is produced. The solution to this problem of knowledge "superabundance" is the creation of information infrastructures that make knowledge available in a methodical, technologically advanced and modern way. Specifically, new infrastructures are supposed to ensure that targeted actors efficiently negotiate in an information-rich environment and receive timely and relevant knowledge, information and data. In addition, new information infrastructures are expected to reduce the waste of time and resources that results from the reinvention of already-existing technologies. Thus, the I \& D model is a model of rationalization in the context of information "superabundance", with a prescriptive emphasis on the creation of new infrastructures designed to improve the flow of knowledge across different institutions.

A few further features of the I \& D model are worth noting. First, the I \& D model of science-industry relations is linear: knowledge generation is followed by dissemination and then utilization. The transfer of existing knowledge across science-industry boundaries takes place without any transformation of that knowledge. At most, information is condensed, or when necessary, translated. Second, the I \& D model does not assume personal contact between scientists and industry. A scientist's primary role is that of knowledge producer, although he may be asked to avoid "unnecessary" or redundant publications and to provide titles and abstracts that may be easily understood by others (for example, President's Advisory Committee 1963). Even here, specialized agencies and archival journals, rather than the scientists themselves, are expected to undertake the bulk of the required work.

\section{The German Case}

Arguably, the I \& D model has been the dominant model in German discourse on "technology transfer" issues since the 1960s. Specialized journals, for example, "Nachrichten für Dokumentation", which was established in 1950, reinforced the I \& D model within the domestic context. The first major national public policy statement reflecting I \& D commitments, however, did not emerge until 1962, when the federal 
accounting office ("Bundesrechnungshof") issued the following statement:

"The solution to the problem of how latent knowledge can be brought to interested parties is essential for the competitiveness of modern, industrial communities and so falls under the purview of government responsibility. The retrieval of knowledge ... is a tool to considerably improve performance in science, the economy and public administration" (Bundesrechnungshof 1962: 23).

Even following this statement, little was done until the first major federal government program was introduced in the mid seventies. The focal point of the I \& D program 74-77 (BMFT 1975) was the creation of large, specialized information centers ("Fachinformationszentren"), under the auspices of the federal government. The general idea of information services remained central in the following years; even though a shift towards a more market-oriented view of information services emphasized that the role of such innovation offices was a private, not public, responsibility (Bundesrechnungshof 1983; BMFT 1985). Finally, in the 1990s, "information policy" was refocussed on information and communication technologies (BMBF 1996, 2002) within the context of an emerging "information society" for example, as in the Bangemann Report (High-Level Group on the Information Society 1994).

Since the 1970s, there has been a consistent focus on small and medium sized enterprises (SMEs) as a target group of I \& D activities. Before, technology policy focused more or less exclusively on big business and big science (BMwF 1969). Compared to large companies, SMEs are seen as informationally disadvantaged and therefore in need of specialized assistance concerning information mediation and dissemination. Thus, in addition to more centralized public and private structures, decentralized mediating infrastructures, including diverse counseling agencies, were established with the explicit aim of offering SMEs "qualified dialogue with a knowledgeable partner" (Ockenfeld 1984: 44f). That is, specialized agencies sought to inform SMEs of industry-relevant technological developments, through targeted counseling in the SME client's sector of interest. In conformity with the I \& $\mathrm{D}$ model more generally, however, such agencies did not coordinate personal contacts between producers and users of scientific knowledge nor did they incorporate the idea of feedback loops between different stages of the innovation process. 


\section{The American case}

In the United States, the Sputnik Shock is usually regarded as the starting point of modern I \& D activities. (Johnson and Teske 1997: 46; see also Krieger 1987: 258). On the institutional side, this event resulted in two main innovations, as the American government sought to respond to the Soviet colonization of space. First, the state founded several institutions and, relatedly, developed new legislation designed to spur on innovation through "technology transfer" between academic and industry. Notably, the National Science Foundation created the "Office of Science Information" in 1958 and, in the same year, Congress established a Science Information Council and the 1958 Defense Education Act to expand technology-related education and establish the Defense Advanced Research Projects Administration (DARPA) (Johnson and Teske 1997: 46). Second, the federal government increased funding for research and development - a particularly remarkable development given the alreadystrong levels of federal research and development support post World War II. This increased funding led to calls for greater public accountability, and subsequently, the creation of I \& D agencies to facilitate the public diffusion of state-funded research and encourage its commercial applications. For example, NACA, later NASA, was given an explicit mandate to publicly disseminate space research in 1959, following concerns about the "practical" implications (that is, commercial applicability) of space research. Following criticisms by Congress, the NASA took a further step by declassifying "uncritical" research outcomes and making them freely available through "regional dissemination centers" all over the United States. Thus, as in Germany, the United States administration actively fostered the I \& D model of technology transfer, typically by establishing federally funded research institutions and then encouraging them to share the results of "pure" scientific research with industry counterparts.

As in the German case, the I \& D model was explicitly used as the basis for formulating state policy concerning research, at least on occasion. For example, Eugene Foley of the Small Business Administration argued, in the mid-1960s, that the American federal government:

"has an obligation to develop a workable system of utilizing this enormous reservoir of scientific information so that its benefits can be transmitted to business both large and small in order to provide the ingredients necessary for an accelerated growth in our civilian economy" (cited in Rosenbloom 1965: 6). 
Thus, relevant American parties tended to conceive of basic research as contributing to a "reservoir" of knowledge, which simply needed to be tapped by industry to ensure national economic progress. This confidence in the transferability of academic knowledge to the industrial domain would wane with the advent of the "cooperation model" of technology transfer: the translation effort that is necessary to transfer knowledge from one context to another becomes a recurring theme in the new model.

\section{The cooperation model}

Studies of technology transfer that were conducted under the I \& D model suggested the limitations of such a model for speeding up the innovation process. In particular, the idea that research outcomes more or less automatically "fall-out" or "spill-over" from the academic to industrial domain was met with increasing scepticism, as researchers pointed out that many potential users, especially SMEs but also "ordinary people", have difficulty understanding "raw" scientific information (see, for example, Myers 1966). Partly, this is because scientific jargon is hard to understand for non-scientists, so that a translation effort is necessary. But, in more general terms, the fact that potential users have access to documented knowledge is not, in itself, enough to stimulate innovation based on this knowledge.

Taking this insight into account, the cooperation model emphasizes that science and technology transfer can only be successful if scientists and practitioners actively exchange their ideas through immediate personal contact. This may be achieved informally or formally, for example, through personnel exchanges between research institutions and industrial partners. Mediators (like technology transfer offices) shall help to establish contacts and to clear up misunderstandings. Thus, in this model, actual or perceived "cultural gaps" between science and the economy are seen as the key problem. These gaps can only be bridged by personal trust.

In contrast to the I \& D model, which implies a linear and hierarchical process of transmitting existing knowledge, the cooperation model understands "transfer" as a dialogue among partners from different institutional backgrounds. Transfer is no longer conceptualized as a one way street. Rather, scientists engage in cooperation, learn about the technological needs of their (industry) partners and redraw their research agenda accordingly. Thus, the cooperation model 
introduces an element of feedback even though scientists are still seen as the primary knowledge producers in the exchange.

Notably, although the cooperation model stresses the institutional integrity of science (and of economy as well), it implies an important change of the role of science in the utilization of scientific knowledge. Scientists, as transfer partners, and scientific institutions, as mediators, are expected to get actively involved in the process of technology transfer.

\section{The German Case}

The cooperation model gained prominence in German science and technology policy during the second half of the 1970s and dominated technology transfer discourse during the 1980s. During this period, official statements of major science organizations relied explicitly upon the cooperation approach to academic-industry ties (Wissenschaftsrat 1986, Hochschulverband 1991). Notably, this meant a shift in the perception of university teaching and research, with a stronger emphasis on their role in resolving the "practical" problems of the economy. At the same time, the model upheld a clear distinction between producers and appliers of knowledge (or to put it another way: between clients and servers). In 1986, the German Research Council characteristically argued that:

"By cooperating with the economy, higher education institutions gain to a larger extent the opportunity to orient teaching and research to practical developments and needs. Research outcomes can be brought to the economy faster, and the innovative potential of the higher education institutions can be emphasized more. This helps the higher education institutions to better fulfill their primary missions in research and teaching as well" (Wissenschaftsrat 1986: 14).

Historically, then, the cooperation model was very much embedded in concepts of the regionalization of the university and in those of broader changes in the national economic structure ("Strukturwandel"). At that time, "innovation" became a key concept in German discourses on the role of technology in economic development. For instance, although the notion of a technological gap between Europe and the United States had already been discussed in the late sixties (OECD 1968) and the term "innovation" can be found in information 
policy papers of the mid-1970s (see, for example, BMFT 1975), it is not until the Commission on Economic and Social Change in 1977 and the federal government paper on technology policy for SMEs in 1978 that innovation is consistently emphasized as the key to industry competitiveness, particularly for SMEs (Kommission für wirtschaftlichen und sozialen Wandel 1977, esp. pp. 255-264; BMFT/BFWi 1978). Both papers describe cooperative technology transfer as a means of advancing innovation and emphasize the role of specialized agencies in this process:

"This [the promotion of specialized technology transfer offices] would be a decisive contribution to the modernization of the national economy and would facilitate future processes of structural adaptation" (Kommission für wirtschaftlichen und sozialen Wandel 1977: 287).

In practice, technology transfer offices have been found in almost every university in Germany since the late 1970s. Although classical I \& $\mathrm{D}$ activities have always been a central task of university transfer offices, it became apparent that information sharing is only a first step, preceeding more active cooperation between academic and industrial partners.

By the late 1970s, the mission of transfer offices, always marked by a strong regional orientation (Krücken 2003), became explicitly tied to university regionalization projects. Early project reports insist upon the necessity of linking up cooperative technology transfer, innovation, and the structural changes in the regional economy (for example Allesch et al. 1979, Kayser 1981, ITZ 1984). In addition, during the same period, the so-called "science shops", offering knowledge transfer services to ordinary people and non-profit organizations, were established. While depicting themselves as an anti-capitalist and emancipatory countermovement to transfer offices, science shops echo their "capitalist" counterparts insofar as they focus on the dialogue between culturally different partners of equal status in a given region (academic researchers, nonprofit organizations, and ordinary people). They emphasize the increasing relevance of science in society, in general terms, and try to direct science to the needs of external constituencies. ${ }^{3}$

In the late 1970s and early 1980s, some German researchers appeared to find the idea of an increasing industrial or, more broadly, "societal" relevance of academic research appealing. This was due to a common, but in hindsight false, belief that changes in demographic structure would lead to a dramatic decrease in university enrollments during the 
1980s, hence making universities the potential object of down-sizing activities (Webler 1984). Thus, university researchers and administrators embraced the idea of new goals and tasks that helped to legitimize ongoing state support for higher education institutions (Neusel and Teichler 1980). In sum, the development of science and technology transfer offices appeared attractive to parties seeking to proactively reaffirm the ongoing relevance of universities when student enrollment figures were supposed to drop.

\section{The American case}

The late 1960s and early 1970s brought about an important change in university functions, albeit one that was somewhat overshadowed by the students' rebellion of the same period. Specifically, the state-universityhoneymoon (Roy 1972: 956) - and with this, the relative distance of academic science and industrial research - came to an end. "Honeymoon" is meant to describe the period of far-reaching state funding for universities which we described above. An unintended effect thereof is a decrease of universities' efforts to apply for other funding sources:

"At one time, industry was a prime supporter and defender of academic institutions. During the last two decades, however - while universities fell into dependence on government - industry and universities have been estranged. ... A closer cooperation of academic scientists and dynamic elements of industry could lead to effective actions" (Abelson 1974: 1251; see also Brodsky et al. 1980: 9).

As this quote illustrates, there were broad calls for a renewed role for industry in the financing of university research. In general terms, in the context of declining state funding levels, which created new challenges for the completion of existing research projects, industry-academic ties were seen as a possible alternative source of financing (NSF 1982: 3; Dedijer 1970). In this situation, the idea of "service" was specifically evoked as the necessary "third mission" of universities.

"The initial dilemma in attempting to meet the new demands being made on our universities results from an uncertainty about our purpose. For anyone associated with the university, the problem revolves around that black pit called service. It is particularly appealing in the era of large, perhaps overactive, universities to define our fundamental missions as basic research and teaching. It seems 
doubtful, however, that we can demote service to a second-class position. President James Perkins of Cornell views service differently, as a third and equal mission of the university. Whether it is what we want, it is much closer to what we have" (Kash 1968: 1315).

Thus, "service" is re-emphasized as one of the core missions of universities. There is, in this way, a commitment, to broader public "accountability" in the form of a marked "service" orientation, which includes renewed industry-academic ties. It is clearly this latter aspect in which we are interested in this paper, and which became subject of political interest in the following years.

Along similar lines, in his message to the congress on March 16, 1972, President Nixon urged the National Science Foundation to "determine effective ways of stimulating non-Federal investment in research and development and of improving the application of research and development results" (NSF 1982: 15). In this way, declining state funding was linked both to the need for increased academic-industry collaboration and to increased expectations that academic research justify existing public finances by producing results directly beneficiary to the national economy.

The National Science Foundation reacted to these new expectations by initiating experimental programs to foster university-industry interaction, notably including the Cooperative Research Centers and the Innovation Centers, established in 1973, followed by the UniversityIndustry Cooperative Research Projects in 1978 (NSF 1982: 16; 9; Asian Productivity Organization 1989: 4; Gray and Walters 1998). Despite these efforts, a 1978 domestic policy review by the Carter administration found university-industry cooperation in research "subject to improvement".

Ultimately, the new interest in academic-industry ties was expressed in two seminal pieces of legislation, both oriented to the new "practical" role for universities in the national economic project, but nevertheless emphasizing different aspects of this role: the Stevenson-Wydler Act, established to support university-industry cooperation; and the BayhDole Act, enabling universities to hold title to inventions funded by federal government sources and thus fostering the entrepreneurial activity of the university itself. While we will deal with the latter one in the following section on the blurring of boundaries model, we will now take a closer look at the Stevenson-Wydler Act, which we interpret as a centerpiece of the cooperation model. In the paragraph on "congressional findings", the act states: 
"Many new discoveries and advances in science occur in universities and Federal laboratories, while the application of this new knowledge to commercial and useful public policies depends largely upon actions by business and labor. Cooperation among academia, Federal laboratories, labor, and industry, in such forms as technology transfer, personnel exchange, joint research projects, and others, should be renewed, expanded, and strengthened" (§3701 (3)).

This quote nicely encapsulates the major premises of the cooperation model, including the notion of give and take between universities and industries and the form that this cooperation should take - namely, technology transfer and joint research. In general terms, the StevensonWydler Technology Act prototypically laments a lack of comprehensive national policy to enhance technological innovation for commercial and public purposes, while calling for renewed cooperation among academia, federal laboratories, and industry through establishing cooperative research center $(\S \S 3701-3702) .{ }^{4}$ It also requires federal laboratories to establish technology transfer offices.

The Stevenson-Wydler Act is the first in a series of legislative steps towards "cooperation" in this era. ${ }^{5}$ Nevertheless it should be noted that cooperation does not imply equal input by academics and industrial partners into the cooperative agreement. The roles of the partners involved are clearly separated, as the following quote from the National Science Foundation illustrates:

"In particular, the Government will support research activities that result in new knowledge from which commercial technology may be ultimately derived. However, it is uniquely the industry's role to translate this knowledge into commercial processes and products, and to support research and development where necessary to complement that supported by the Federal Government" (NSF 1982: 6).

Bozeman (2000: 633) points to this "division of labor" even more clearly:

"The cooperative technology policies ... depend greatly on universities and government laboratories. The logic is simple: universities and government labs make, industry takes."

In piecemeal fashion, new acts were added to extend the StevensonWydler Act, which was widely criticized as "toothless" since Congress initially withheld necessary funding, and because technology transfer offices were often introduced on a "ceremonial" basis only, for example, 
being (inadequately) staffed by one part-time employee, and without any formal agenda (Rahm et al. 1988: 970).

In 1982, the Small Business Innovation Development Act was passed, requiring federal agencies to provide set-aside funds for small business R \& D. In 1984, the National Cooperative Research Act was legislated, supporting the idea of collaborative research between firms, federal laboratories, and universities by introducing an exemption from anti-trust legislation. The 1986 Federal Technology Transfer Act authorized national laboratories to enter into cooperative $\mathrm{R} \& \mathrm{D}$ agreements with private firms and to negotiate the licensing agreements ${ }^{6}$ and the 1988 Omnibus Trade and Competitiveness Act established centers for transferring manufacturing technology. The 1989 National Competitiveness Technology Transfer Act extended the 1986 Technology Transfer Act to all federal laboratories; and the 1991 Defense Authorization Act linked defense laboratories with state and local governments and small businesses (Slaughter and Leslie 1997; Bozeman 2000). In this way, the acts mentioned above extended the idea of cooperation between universities and private laboratories.

\section{The blurring of boundaries model}

While the cooperation model takes for granted - and even emphasizes clear institutional boundaries between science and the economy, the $\mathrm{BoB}$ model assumes that these boundaries are becoming increasingly permeable, diffuse and, in some cases, "blurred".

Analytically, this model has two variants. The first focuses on the emerging entrepreneurial activity of the university, which is understood as an economic actor in its own right, engaging in licensing activities and/or fostering spin-offs. In becoming entrepreneurial the university transcends its institutional identity and undermines traditional boundaries.

The second variant emphasizes the embeddedness of academic knowledge production in a comprehensive innovation process, which is regarded as highly complex and is often described with metaphors of systems or networks. This model highlights, for example, the interaction of the systems' components or feedback loops.

These network features clearly contrast with the cooperation model's more simple and linear structure. The cooperation model focuses on mediated and straightforward - mostly - dyadic relation between scientists and practitioners. In contrast, the more complex network model 
makes it harder or even impossible to differentiate a well-defined academic role from an economic one. As a result, also in the network variant of the $\mathrm{BoB}$ model the institutional boundaries of the economy and of the academia are blurred.

\section{The German case}

In German discourse, the BoB model emerged in the 1990s, particularly in federal government and the European Union policy papers. Science at least in part - is now interpreted as an element of a comprehensive innovation process, for which the network form seems to be the most appropriate structure:

"Research is not an end in itself. In the long run, research should lead to economic growth and new jobs. All parts of the innovation process, starting with basic research up to the diffusion of new products and procedures, should be linked up" (BMWi/BMBF 2002: 35).

Indeed, science and technology related policies now routinely postulate the efficiency and effectiveness of heterogeneous networks. Networks of all kinds - regional clusters, innovation networks, excellence networks and above all competence networks - are promoted as the means to "secure the competitiveness of Germany in the international competition" (BMBF 2000: 60). Likewise, the European Union explicitly supports networks through its financing of "networks of excellence", and implicitly supports them by making the participation of institutions from different member states a prerequisite for European funding.

The widespread belief in the centrality of network structures to successful technology transfer is expressed in condensed form in the slogan of the internet portal "kompetenznetze.de", an initiative of the federal research department: "Innovations require Networks". The technology transfer offices of universities increasingly engage in networking activities as well. Indeed, for some of them networking with other networkers even seems to become the ultimate raison d'être (Krücken and Meier 2003).

In addition to the emphasis on complex networks some cautious steps towards the entrepreneurial university can be observed in German discourse as well. For example, technology transfer policy in this period focuses on two central issues: patents and spin-offs, both of which imply the economic activity of individual scientists or universities. The extent of 
the debate around patents and spin-offs is symptomatic of an "economized" perception of the scientific sphere. Nevertheless, in contrast to the belief in networks the idea of entrepreneurialism is still contested as the following quote from a key professors' lobby organization shows: "Science transfer is cooperation with enterprises. The scientists as entrepreneur must be an exception" (Hochschulverband 1991: 215).

Spin-offs are fostered by different activities undertaken by the federal government (for example the program EXIST) and by several states ("Länder"). In addition, they become an important field of activity for transfer offices as well (Meier 2001). Until recently, due to the so called teacher exemption clause ("Hochschullehrerprivileg") the title to all potentially patentable innovations belonged to the individual researcher. In 2002 the legal situation changed and the universities became responsible for patenting activities. This development changes the very nature of transfer policies towards patenting. While traditional policies reduced technology transfer offices to centers giving legal and economic advice to individual inventors, the new law brings a new task to universities, allowing and encouraging them to become actively entrepreneurial at the organizational level. Since existing transfer offices do not meet the professional requirements for licensing activities, new infrastructures are created to fulfill the new institutional tasks.

Alongside organizational innovations in universities that reflect the new BoB model, there are activities on a larger scale as well. For instance, the federal government is now funding patent exploitation agencies ("PVA") in each of the German states. Yet it remains an open question whether or not these structures will be self-sustaining after the initial federal funding runs out.

\section{The American case}

In the United States, the blurring of boundaries model takes the shape of the entrepreneurial university. As we have seen, the models presented in this paper are not adopted in strict chronological order: the uptake of a new model does not imply the end of its predecessor. This holds especially true for the cooperation model and the blurring of boundaries model, as both approaches, which imply a somewhat different understanding of the role of universities with regard to the economy, are supported simultaneously.

The Bayh-Dole Act that we see as a milestone of the BoB model was passed in 1980. That very year the Stevenson-Wydler Act, which we 
interpreted as an important expression of the cooperation model, came into existence, too. Probably it is this simultaneity that explains why American authors like Slaughter and Leslie (1997) and Bozeman (2000) do not distinguish between models of cooperation and those of entrepreneurship incorporated in these acts. In fact, these authors assume that both acts (and all follow-ups on the Stevenson-Wydler Act) are driven by the same spirit.

The Bayh-Dole Act entitled universities and SMEs to patent and to issue licenses to inventions developed with federal funding. This Act is commonly recognized as the first significant initiative in the creation of the entrepreneurial university, thrusting university research into the profit-making arena. Or, as Slaughter and Leslie (1997: 46) put it: "In a very real sense the Bayh-Dole Act encouraged academic capitalism." Howard H. Bremer points out in 2001 that the Bayh-Dole Act was "the final step in establishing the strong university-industry connection which nowadays exists in the United States" and that "today, universities operate in an economic climate which ... is entrepreneurially based" (http://www.nasulgc.org/cott/bayh-dohl/bremer_speech.htm, July 13, 2004).

Thus the Bayh-Dole Act was a particularly important symbolic event because many different actors whose opinions otherwise differ, converge in their assessment of its importance for university/industry relations.

Yet, some authors challenge the assumption that the Act is the crucial step towards entrepreneurial activity. For example, they suggest that the Act has had little real effect on university patenting and licensing, and that it was only one among other factors contributing to the related increase in the 1980s and 1990s (see, for example, Mowery et al. 2001).

Nevertheless, the Bayh-Dole Act marks the shift towards a new model in American discourse, though perhaps not in practice. In this model, universities are seen as relevant economic actors, interested in selling the fruit of their research work via patenting and selling licenses, and by spawning start-up companies. This "capitalization of knowledge" (Etzkowitz 1994, 1998) leads to new policy topics and sometimes disputes (cp. Matkin 1997: 95). ${ }^{7}$

Indeed, with the advent of the entrepreneurial university a new ideal emerges: A strong indicator for excellent research used in the Science and Engineering Indicators is research that leads to patents as well as publications in - preferably basic - science journals, and both are seen as "performance" indicators for university researchers (see NSB 2004: O-8). 
While claiming that the existence of the entrepreneurial university has become a truism in American higher education discourse, there is - compared to the German case - only scant political attention to complex innovation networks. Nevertheless, actual network-like cooperation practices, which are in particular highlighted for the Silicon Valley and its heterogeneous actors (Stanford University, venture capitalists, industrial firms etc.) may contribute to the perception of blurring boundaries as well (see, for example, Saxenian 1994, Kenney 2000).

\section{Discussion}

Following from our analysis, it is clear that the debate about how to spur the transfer of knowledge and technology between academia and industry is not a recent phenomenon. In the United States, the discussion began in the late 1950s, and in Germany in the early 1960s. From that time on, as we have argued, not one model but three different models of technology transfer have been advocated in both countries. In the I \& D model, the emphasis was on finding more effective ways of making information about knowledge and technology available to its potential users. Here, academia's knowledge base was seen simply as a reservoir in need of better documentation, and it was imagined that advancements in information technology would suffice to bridge the gap between academia and industry. Similarly, the I \& D model has a relatively straightforward understanding of knowledge, based on the assumption that knowledge may be transferred from one context to another, without being transformed by this transfer. Thus, the logic was that of a linear and hierarchical diffusion from academia to industry, reflecting the scientific optimism of that era.

In the 1970s, however, a more sceptical view of technology transfer emerged in both countries, leading to the emergence of what we have called the cooperation model. Trust in I \& D activities waned, and the hitherto unquestioned linear and hierarchical model of knowledge transfer was criticized. The new model emphasized cultural differences between academia and industry, with the consequence that trustbuilding - through direct interactions, personnel exchanges, and mediating agencies - became the dominant issue. While this model explicitly recognized differences between the academic and industrial contexts, it did not question those differences. Thus, the cooperation model emphasized a much more active and dialogue-oriented role for both academic and industrial researchers, across the different institutional 
contexts, as well as for the organizations in which they are embedded. Furthermore, both in the United States and in Germany the whole discourse on academia and industry links became more encompassing and dramatic in tone. Both institutional contexts were now seen as contributing to innovation, which in turn was seen as of central importance for the economic competitiveness and, hence, economic survival of both countries.

Finally, the blurring of boundaries model took shape, appearing in the 1980s, in the United States, and in the 1990s, in Germany. In this model, the blurring of clear-cut institutional boundaries between academia and industry is seen as a central feature in the overall innovation process, an approach translated into two distinct policy ideas. On the one hand, the university is conceptualized as an economic actor, and entrepreneurial activities not only of individual faculty, but of the organization as a whole are encouraged. This approach is in obvious contrast to the cooperation model, where the institutional distinctiveness of universities as compared to economic firms is recognized but not treated as something which had to be overcome. On the other hand, a network-structure is sought, to facilitate the linking up of universities, other research organizations, different kinds of firms, and political agencies, all of which are seen as different nodes in the innovation process. This clearly marks a strong departure from the linear approach of the first two models, as complex interactions and feedback loops are highlighted.

Nevertheless, similarities between both national systems should not be overdrawn. Our analysis has brought attention to equally strong differences. While in Germany the three models succeed each other in a clear chronological order, the American picture is more strongly marked by overlapping models, in which, beginning with the I \& D model, aspects of subsequent models are added in piecemeal fashion. In addition, some more specific differences have become obvious. According to our analysis, rules and regulations are the most important elements framing the American discourse. In particular, from 1980 onwards, the Bayh-Dole Act served as a focal point for all relevant actors dealing with universityindustry relations, reflecting, but in the contemporary context, longstanding American interest in the relevance of universities to economic performance. Such a discursive reference point seems to be missing in Germany. Here, instead, a broader cultural and political debate on the appropriate role of universities in innovation systems emerged, in which up to the 1990s - the political and academic elites were strongly divided on whether universities should become entrepreneurial or not. 
Another important difference between the two national contexts is the role played by the concept of the network. The idea of the network seems to play a much stronger role in Germany, where it has acquired a myth-like status in current discourse. In contrast, in the United States, innovation networks, though heavily discussed and promoted in academic discourses, are significantly less visible in political discourse and related programs and legislation. This difference seems to reflect the embeddedness of university-industry relations in different cultural settings and, ultimately, polities. The assumption that heterogeneous networks are superior to other forms of exchange and cooperation may be due to an emphasis, in German political culture, on interest mediation and the inclusion of different, even marginal actors. For example, in Germany, there is an emphasis on broad participation of SMEs and regional political agencies of all kinds, which cannot be found in the United States. This tendency in Germany is further fueled by the European Union, which is also heavily promoting the network idea through a variety of programs and by making the participation of different institutions from different member states obligatory for European research funding. In this, the global trend towards closer relationships between academia and industry is mediated by national political and cultural traditions, which continue to exhibit marked differences. Thus, although both the German and American national discourses show a common trend towards the blurring of boundaries between academia and industry, in an individualist polity, like the American one, the entrepreneurial university and the entrepreneurial researcher have become the dominant role model, while in a "neo-corporatist" polity, like the German one, a comprehensive innovation network is seen as the way to success. This opens up interesting questions concerning international comparisons in higher education and innovation policy, which go far beyond the cases we analyzed here.

\section{Acknowledgements}

The results presented here are part of a larger comparative research projects on technology transfer discourses and structures in Germany and the United States. This project was made possible by a grant from the Deutsche Forschungsgemeinschaft (DFG Grant KR 2011). We would like to thank Elaine Coburn who commented on earlier drafts of this paper and helped to clarify our arguments. 


\section{Notes}

1. We examined written documents of central science and political organizations, legal texts, and research journals.

2. These discourses are embedded in broader societal developments which are to be analyzed from a macro-sociological perspective. Here, one can draw, for example, upon neo-marxist models of political economy, or on the world-polity model in sociology's neo-institutionalism. For an attempt to analyze technology transfer discourses from these competing perspectives see Coburn 2007).

3. In Germany, however, science shops did not gain much importance in contrast to other countries, especially the Netherlands (Kleijer 1984). Currently they seem to be rediscovered by the European Union. The alleged comeback of this institution is described by Fischer et al. (2004).

4. The emergence of the cooperative model does not imply the end of information and documentation efforts. This is nicely illustrated by the act itself, as it also aims at enhancing information and documentation mechanisms ( $\$ 3705 \mathrm{a}(4)$ ).

5. Obviously this holds true for the 1980s only. The first legislative action on cooperation is the Morrill Act of 1862, through which land-grant universities were established.

6. The ability to licensing itself is part of the BoB model, though.

7. The "economized" perception of universities is mirrored by "economized" language. AUTM points out in their FAQ (http://www.autm.net/pubs/survey/qa.html, July 13, 2004) that revenues out of licensing help advancing research and education "through reinvestment in the academic enterprise", and the Government University Industry Roundtable is created to "improve the productivity of a nation's research enterprise" (GUIRR 1990: ii).

\section{References}

Abelson, P.H. (1974). 'Editorial: Academic science and industry', Science, 183: 1251.

Allesch, J., Fiedler, H. and Scheffen, C. (1979). Pilotstudie Technologietransfer. Bericht für die Zeit vom 1.12.1977 - 1.12.1978 (3rd edition) Berlin: TU, Kontaktstelle Planung im öffentlichen Dienst.

Asian Productivity Organization (ed.) (1989). Industry-Academic-Government Collaboration for Technology Development. Tokyo: Asian Productivity Organization.

Bundesministerium für Bildung und Forschung BMBF. (2000). Bundesbericht Forschung 2000. Bonn: BMBF.

Bundesministerium für Bildung, Wissenschaft, Forschung und Technologie BMBF, (1996). Information als Rohstoff für Innovation: Programm der Bundesregierung 1996-2000. Bonn: BMBF.

Bundesministerium für Bildung, Wissenschaft, Forschung und Technologie BMBF, (2002). Informationen vernetzen - Wissen aktivieren. Strategisches Positionspapier. Bonn: BMBF.

Bundesministerium für Forschung und Technologie BMFT. (1975). Das Programm der Bundesregierung zur Förderung der Information und Dokumentation (IuD-Programm) 1974-1977. Bonn: BMFT. 
Bundesministerium für Forschung und Technologie BMFT. (1985). Fachinformationsprogramm der Bundesregierung 85-88. Bonn: BMFT.

Bundesministerium für Forschung und Technologie / Bundesministerium für Wirtschaft BMFT/BMWi. (1978). Forschungs- und technologiepolitisches Gesamtkonzept der Bundesregierung für kleine und mittlere Unternehmen. Bonn: BMFT/BMWi.

Bundesministerium für wissenschaftliche Forschung BMwF. (1969). State, Science and Economy as Partners. Berlin/Wien: Koska.

Bundesministerium für Wirtschaft und Technologie / Bundesministerium für Bildung und Forschung BMWi/BMBF. (2002). Innovationspolitik - Mehr Dynamik für zukunftsfähige Arbeitsplätze. Bonn: BMWi/BMBF.

Bozeman, B. (2000). 'Technology transfer and public policy: A review of research and theory', Research Policy 29: 627-655.

Brodsky, N.H., Kaufman, H.G. and Tooker, J.D. (1980). University / Industry Cooperation: A Preliminary Analysis of Existing Mechanisms and Their Relationship to the Innovation Process. New York: New York University.

Bundesrechnungshof. (1962). Untersuchung über die wissenschaftliche Dokumentation in der Bundesrepublik Deutschland. Frankfurt/M: Bundesrechnungshof.

Bundesrechnungshof. (1983). Gutachten des Präsidenten des Bundesrechnungshofes als Bundesbeauftragter für die Wirtschaftlichkeit in der Verwaltung über die Fachinformation in der Bundesrepublik Deutschland. Frankfurt/M: Bundesrechnungshof.

Coburn, E. (2007). Commodification or Rationalization? Yes, please! Technology Transfer Talk in the Canadian Context, in Krücken, G., Kosmützky, A. and Torka, M. (eds.), Towards a Multiversity? Universities between Global Trends and National Traditions. Bielefeld: transcript, pp. 226-250.

Dedijer, S. (1970). 'The R \& D depression in the United States', Science 168: 344-345.

Etzkowitz, H. (1994).'Knowledge as Property, MIT and the Debate Over Academic Patent Policy', Minerva Winter 33(4): 383-421.

Etzkowitz, H. (1998). 'The norms of entrepreneurial science: Cognitive effects of the new university-industry linkages', Research Policy 27: 823-833.

Ezkowitz, H. (ed.) (2000). 'Triple Helix', Research Policy Special Issue 29(2): 109330.

Etzkowitz, H., Webster, A. and Healey, P. (eds.) (1998). Capitalizing Knowledge. New Intersections of Industry and Academia. Albany: State University of New York Press.

Fischer, C., Leydesdorff, L. and Schophaus, M. (2004). 'Science Shops in Europe: The public as stakeholder', Science \& Public Policy 31: 199-211.

Gray, D.O. and Walters, S.G. (eds). (1998). Managing the Industry / University Cooperative Research Center: A Guide for Directors and Stakeholders. Columbus: Battelle Press.

Government-University-Industry Research Roundtable GUIRR. (1990). The Academic Research Enterprise within the Industrialized Nations: Comparative Perspectives. Report of a Symposium. Washington: National Academy Press.

High-Level Group on the Information Society. (1994). Europe and Global Information Society. Brussels: Bangemann Report Recommendations to the European Council.

Deutscher Hochschulverband. (1991). Das Berufsbild des Universitätslehrers. Thesen mit Erläuterungen. Forum des Hochschulverbandes 55. Bonn: Hochschulverband.

Innovationsförderungs- und Technologie-Transfer-Zentrum der Hochschulen des Ruhrgebietes ITZ. (1984). Endbericht des Modellversuches "Innovationsförderungs- 
und Technologie-Transfer-Zentrum der Hochschulen des Ruhrgebietes (ITZ) zum 31.01.1984",

Johnson, R.J. and Teske, P. (1997). ‘Toward an american industrial technology policy', in Lee, Y.S. (ed.), Technology Transfer and Public Policy. Westport: Quorum Books, pp. $42-60$.

Kash, D.E. (1968). 'Research and development at the University. The direction of federal support and opportunities for response by consortia are changing', Science 160: 1313-1318.

Kayser, A. (1981). Universität Kaiserslautern als Motor für die Region Westpfalz. Kaiserslautern: Planungsgemeinschaft Westpfalz.

Kenney, M. (ed.) (2000). Understanding Silicon Valley. The Anatomy of an Entrepreneurial Region. Stanford: Stanford University Press.

Kleijer, H. (1984). 'The role of science shops in research and education - new relation between university and region', in Webler, W.-D. (ed.), Hochschule und Region: Wechselwirkungen. Weinheim: Beltz, pp. 311-321.

Kommission für wirtschaftlichen und sozialen Wandel. (1977). Wirtschaftlicher und sozialer Wandel in der Bundesrepublik. Gutachten der Kommission. Göttingen: Schwarz.

Krieger, W. (1987). Zur Geschichte von Technologiepolitik und Forschungsförderung in der Bundesrepublik Deutschland: eine Problemskizze. Vierteljahreshefte für Zeitgeschichte, pp. 247-271.

Krücken, G. (2003). 'Learning the "New, New Thing": On the Role of Path Dependency in University Structures', Higher Education 46: 315-339.

Krücken, G. and Meier, F. (2003). "Wir sind alle überzeugte Netzwerktäter". Netzwerke als Formalstruktur und Mythos der Innovationsgesellschaft', Soziale Welt 54: 71-92.

Matkin, G.W. (1997). 'University technology transfer and the problems of conflict of interest', in Lee, Y.S. (ed.), Technology Transfer and Public Policy. Westport: Quorum Books, pp. 95-109.

Meier, F. (2001). Im politischen Netz. Zur Organisationssoziologie universitärer Transferstellen. Master's thesis, Department of Sociology, University of Bielefeld.

Mowery, D.C., Nelson, R.R., Sampat, B.N. and Ziedonis, A.A. (2001). 'The growth of patenting and licensing by U.S. Universities: An assessment of the effects of the Bayh-Dole Act of 1980', Research Policy 30: 99-119.

Myers, S. (1966). 'Summay of the Proceedings', in Proceedings of a Conference on Technology Transfer and Innovation, Statler Hilton Hotel, May 15-17, 1966, National Planning Association, Washington.

Neusel, A. and Teichler, U. (1980). Neue Aufgaben der Hochschulen. Werkstattberichte 3. Wissenschaftliches Zentrum für Berufs- und Hochschulforschung Gesamthochschule Kassel, Kassel.

National Science Board NSB. (2004). Science and Engineering Indicators 2004. Arlington: National Science Foundation.

National Science Foundation NSF. (1982). University-Industry Research Relationships: Myths, Realities and Potentials. Fourteenth Annual Report to the National Science Board. US Government Printing Office, Washington.

Ockenfeld, M. (1984). 'Informationsvermittlung und Wissenstransfer', in Müller, H. and Strauch, D. (eds.), Von der Dokumentation zum Wissenstransfer. KtK-Workshop in Frankfurt am Main 26. und 27. März 1984, pp. 41-49. 
Organisation for Economic Cooperation and Development OECD. (1968). Gaps in Technology. General Report. OECD, Paris.

President's Advisory Committee. (1963). Science, Government, and Information. The Responsibilities of the Technical Community and the Government in the Transfer of Innovation, Weinberg Report, Washington.

Rahm, D., Bozeman, B. and Crow, M. (1988). 'Domestic technology transfer and competetiveness: An empirical assessment of roles of university and governmental $\mathrm{R}$ \& D Laboratories', Public Administration Review 48: 969-978.

Rosenbloom, R.S. (1965). Technology Transfer - Process and Policy. An Analysis of the Utilization of Technological By-Products af Military and Space $R \& D$. NPA Special Report No. 65. NPA, Washington.

Roy, R. (1972). 'University-Industry Interaction Patterns', Science 178: 955-960.

Saxenian, A. (1994). Regional Advantage. Culture and Competition in Silicon Valley and Route 128. Cambridge: Harvard University Press.

Slaughter, S. and Leslie, L.L. (1997). Academic Capitalism. Politics, Policies and the Entrepreneurial University. Baltimore: Johns Hopkins University Press.

Slaughter, S. and Rhoades, G. (2004). Academic Capitalism in the New Economy. Baltimore: Johns Hopkins University Press.

Webler, W.-D. (ed.), (1984). Hochschule und Region - Wechselwirkungen. Weinheim: Beltz.

Wissenschaftsrat. (1986). Stellungnahme zur Zusammenarbeit zwischen Hochschule und Wirtschaft. Köln: Wissenschaftsrat. 